\title{
The Enlightenment and the Greek cultural tradition ${ }^{\text {th }}$
}

\author{
Paschalis M. Kitromilides $\underline{a}, \underline{b}$ \\ ${ }^{\mathrm{a}}$ University of Athens, Athens, Greece \\ ${ }^{\mathrm{b}}$ Institute for Neohellenic Research/National Hellenic Research Foundation, Athens, \\ Greece
}

3 July 2009.

\begin{abstract}
In this paper I attempt to situate the expression of the secular culture of the Enlightenment in the Greek context into the broader intellectual and spiritual tradition defined by the Greek language. The analysis points at the breaks introduced into this tradition by the Enlightenment (in historical and geographical conceptions, in scientific and political thought and in the understanding of the classics) but it also argues that despite its novelty the Enlightenment shared a considerable heritage with the broader Orthodox religious culture into which it was transmitted in Southeastern Europe. This point is illustrated by reference to biographical evidence, supplied by the life histories of three important exponents of the Enlightenment writing in Greek (E. Voulgaris, Iosipos Moisiodax and N. Doukas). The complex relation between the Enlightenment and earlier Greek intellectual traditions is underlined in conclusion.
\end{abstract}

Keywords: Enlightenment; Culture; Tradition; Greek language; History

In the history of culture, despite methodological debates, redefinitions of conceptual agendas and expanding frontiers of subject matter, the exploration of traditions remains a central concern. What is precisely meant by the idea of tradition is still another issue of disagreement and contention, but as it has been rather reasonably suggested "it is virtually impossible to write cultural history without it". 1 The idea of a cultural tradition provides a focus upon a body of sources held together by certain recognizable criteria, that could provide the subject matter of historical research and reflection. Studying and thinking about tradition does not necessarily involve reification and ideology as the critics of conventional cultural history might contend. It could very well be, as it is mostly the case in pertinent work in contemporary scholarship, an exploration of adaptation and reception, cultural encounters and osmosis, unity and diversity. Such possibilities in the study of cultural traditions can 
be seen to be immanent in the observation and critical reappraisal of the Greek intellectual tradition, that is the multiple forms of creative expression in the Greek language through the centuries. In this case language is the fundamental criterion defining a long and persisting collective intellectual presence, marked by radical discontinuities and profound transformations, but still conscious of itself, on the level of intellectual discourse, as a tradition. This self-awareness is primarily exemplified by a dialogue across the centuries and historical periods, a dialogue registered in the creative use of language, in the appropriation and reappropriation of forms of language in order to articulate spiritual, social and political concerns of the communities expressing themselves in Greek at different periods of history.

In contrast to the other ancient tradition of the Mediterranean world, Judaism, which has been held tightly together by its religion across three millennia, the Greek tradition is marked by a radical break in its religious identity at the end of antiquity with the transition from paganism to Christianity, but it managed to survive as a tradition thanks to the continuity of its language, whose successive phases of evolution are marked by much closer affinities to each other by comparison to the evolution of many other languages. On the basis of this criterion a cultural history perspective could develop an understanding of Greece as an evolving intellectual tradition, comprising successive phases of cultural expression including phenomena of traditions within the overall tradition defined by the Greek language, with their interconnections, continuities and discontinuities, transformations and contradictions. The cultural heritage of Modern Greece in particular considered at this more comprehensive level appears as the product of the confluence of diverse, often contradictory, currents of thought and creative expression, often the products of encounters with other cultures and traditions. What I propose to do in this interpretative essay is to put together some reflections and impressions arising from my research on one such creative current of thought within Greek culture. In a certain sense the creative moment in question could be seen to inaugurate what is specifically modern in Greek culture, while at the same time drawing strength and vitality from important resources of earlier Greek traditions.

Conventionally in Greek literary history the cultural moment I propose to discuss is described as the "Modern Greek Enlightenment". The term Enlightenment is used to signify two things. First it denotes the import into Greek thought and education of models originating in the philosophical and scientific culture of Western Europe, the secular civilization of modernity. New concepts, values and modes of expression, in short a different attitude to life and to intellectual activity, made their uncertain appearance into the society of the Greek East in the course of the eighteenth century. Secondly and more substantively the term Enlightenment refers to a greater density in intellectual life, a more pronounced sense of a revival of civilization in the Greek lands and in their broader Southeastern European context, which is observable especially in the fifty years from the Russo-Turkish wars of the 1770s to the Greek 
War of Independence in the $1820 \mathrm{~s} .{ }^{2}$ It is in this second sense, as a period of intellectual revival and soul searching, a period of strivings in the present and hopes for the future that the Enlightenment is a critical and important age in Greek intellectual history: it essentially forms the context of the gradual self-definition of the Greeks as a modern nation.

Most of the stimulus for all this came from new needs and changes in the broader society of Ottoman Southeastern Europe within which the Greek regions had been politically integrated for centuries. The frameworks of thought and the vocabulary for the expression of the new concerns and hopes, however, came in the form of borrowings and imports from Western culture. In the process of transmission the Balkan diasporas of merchants and intellectuals in Central and Western Europe played a crucial part. In this sense Vienna, Budapest, Venice, Trieste and Paris played an equally important role in the revival of Greek and more generally Balkan culture in the eighteenth and early nineteenth centuries as Constantinople, Bucharest, Ioannina, Smyrna, Chios and other lesser centres of commercial and cultural life in Southeastern Europe.

As an intellectual import, transmitted from the non-Orthodox and increasingly secularised cultures of the West, the frame of mind associated with the Enlightenment, represented a break in the post-Byzantine spiritual tradition prevailing in the Greek East under Ottoman rule. This tradition was defined fundamentally by the outlook and values of Eastern Orthodoxy, which comprised as its primary intellectual content the heritage of sacred and classical learning bequeathed by Medieval Byzantium. Appropriately adapted to the realities of the Ottoman conquest, this heritage through its selective reception provided the ideological context of the collective existence of the Orthodox communities of the Balkans and the Middle East from the disappearance of Byzantine rule to the nineteenth century.

The historical significance of the Enlightenment in Southeastern Europe consisted in the attempt of its major exponents to redefine the context of collective existence. It was in this sense that the Enlightenment was perceived by contemporaries and interpreted by subsequent commentators as a break in the traditions of the Orthodox East. The story of this break amounts to the intellectual history of the Greek-speaking world in the eighteenth century. Already traceable in the shape of gropings for intellectual redefinition in the early part of the century, it grew apace around midcentury and escalated into a dispersed movement of cultural change from the 1780s onward. Thus over a time-span comprising the lives of four generations and in widening geographical circles both within and without the Ottoman borders, the gradual growth of Enlightenment currents, although affecting only tangentially, if at all, the intellectual universe of the peasant mass of the population, speeded up reorientations and redefinitions that announced things to come. What I can do here is to present no more than a brief overview of the intellectual content of this movement. 
In attempting to recapture the movement of Enlightenment in Greek culture one has to recover a series of processes of intellectual transformation..$^{\underline{3}}$ A reconsideration of basic philosophical conceptions marked the transition from Neoaristotelianism to rationalism. ${ }^{4}$ The modern scientific outlook was gradually but not painlessly introduced over a time span of many decades. ${ }^{-}$Conceptions of the past and of historical time were secularised and redirected from the sense of a shared past of all Christian peoples to a perception of a distinct historical lineage that connected the modern Greeks with classical hellenism. This was one of the most characteristic intellectual breaks brought about by the secularization of historical thought. The break represented the abandonment of the chronographical literature that carried on an old Byzantine tradition of histories of the world since the Creation or the Deluge, and the replacement of these providential chronicles by a secular historiography. $\underline{6}$

Conceptions of geographical space also changed and the traditional geography of religious pilgrimages gave way to a new geography of civilization. This meant that the descriptions of pilgrimages to the Holy Land and to the great monastic centres of Eastern Orthodoxy, such as Mount Athos and Sinai, which had for centuries defined the geographical horizon beyond the local community, were supplemented and gradually superseded by a new geographical literature that focused on Western Europe and projected before Orthodox consciousness the achievements of cultural change and the progress of the Enlightenment as models to be emulated. ${ }^{7}$ An integral part of the intellectual content of the Enlightenment, therefore, was this journey, as it were, from Jerusalem to Athens and thence to Paris. The intellectual experience of change in basic conceptions of time and space paralleled the social experience of increased geographical mobility which marked the biographies of all those involved in the culture of the Enlightenment.

Changes in the broader intellectual universe provided the context of a fundamental redefinition of political notions and concepts. One of the most pronounced dimensions of the Greek Enlightenment was precisely the transformation of political thought. Traditional conceptions of Christian rulership provided the intellectual basis upon which ideas of enlightened absolutism could be initially elaborated. From the Aristotelian conception of the just prince who rules in the interest of his subjects it was rather easy to make the transition to the idea of a reforming monarchy. In this connection it is very interesting to note the changing role of Byzantine law in the legislative projects of Phanariote princes, ruling in the principalities of Wallachia and Moldavia under Ottoman suzerainty in the eighteenth century. In new legislative codes they attempted to recast the edicts of Christian Roman emperors in order to achieve more efficient administration and to reduce some of the many forms of social injustice such as serfdom and peasant exploitation. ${ }^{8}$ Once reform was acknowledged as part of political ideology, however, new implications and arguments with farreaching consequences were inevitable. The idea of a just and reforming monarchy thus became a component of a theory of political change. The only direction that theory could eventually take was that of liberalism. On the level of political discourse 
our sources register a gradual but steady transition growing apace over time in the fifty years from 1770 to 1820 , which led from a consideration of forms of government to the replacement of conceptions of subject-hood with conceptions of citizenship and to the substitution of the idea of the Orthodox Commonwealth by that of the nationstate. A liberal republican vision eventually emerged as the culmination of the process of ideological change and provided the symbolic vocabulary for the expression of Greek claims and aspirations during the War of Independence.

In this process of cultural and political change the French Revolution, whose impact was felt with increasing intensity in Southeastern Europe from the early 1790s down to the fall of Napoleon in 1815, proved a catalyst in the transformation of political thought. Its ideological principles and rhetoric provided the symbolic language of political radicalism and the models of the Republic of Virtue to guide the aspirations of political change. The year 1789 was the turning point for the emergence of a radical movement in the Balkans, whose protagonists, regardless of their ethnic origin, expressed themselves primarily in Greek. French revolutionary influences also had another effect: they provided the catalyst for ideological polarisation and conflict, especially following the regicide of 1793 and reaching a climax after Napoleon's campaign to Egypt in 1798. The events in France appeared to all those suspicious of the Enlightenment and skeptical about the benefits of cultural change, as a portend of the destruction of society, a source of anarchy and atheism. So the 1790s was a period of radical aspirations and liberal hopes but also a period of attacks and exhortations against the Enlightenment. Militant counter-attacks by the spokesmen of the Enlightenment, the "party of humanity" in the Balkan context, made the three decades from 1789 to 1821 a period of ideological confrontation and conflict. ${ }^{9}$ The debate on the French Revolution was replicated in Greek culture and produced some important statements of social criticism, but also some quite eloquent articulations of the outlook of an alternative religious enlightenment inspired by the values of Orthodox tradition, which was going through its own revival in the second half of the eighteenth century. As a result of the cleavage brought about by the Enlightenment in Greek thought two competing and often hostile visions of the collective destiny of the Greek people have been trying to impose themselves on Greek society ever since the end of the eighteenth century. One was the vision of liberal aspirations, what is commonly known as Westernization; the other is the vision of purity of faith, which visualizes the future of the nation exclusively within the framework of Orthodox authenticity.

In my earlier work I have mostly concentrated on the range of intellectual transitions that make up the content of the Enlightenment in Greek thought. I stressed what was new and unconventional, what was modern and therefore likely to provoke reactions and ideological conflict. ${ }^{10}$ Thinking about the Enlightenment historically however, as a phase in an unfolding process of cultural change, reveals continuities as well as breaks and transitions. I am now coming to a revisionist view which sees the manifestations of intellectual revival in Greek thought in the eighteenth century not 
only as a break with, but also as an integral part of the cultural tradition of the postByzantine society of Southeastern Europe. I believe that this view might allow us to comprehend the resilience of intellectual phenomena, which for the most part had very narrow social bases. It was the vitality they drew from earlier traditions and existing practices, upon which they were grafted, that enabled the manifestations of the Enlightenment to survive and develop, despite the pressures toward marginalization they often encountered. It is, therefore, important for historical understanding and interpretation to consider these sources of strength and bases of continuity that permitted to the Enlightenment to function as an integral rather than as a tangential component of cultural life in Southeastern Europe.

Continuities between the phenomena of intellectual change subsumed under the Enlightenment and the earlier cultural tradition of the Greek East could be traced on many levels: in social practices, in educational experiences, in life histories. As a movement of spiritual renewal the Enlightenment had diverse origins. It was partly the product of the educational experiences and cultural tastes of the first group of secular leaders and scholars to emerge in Greek society since the fall of Constantinople, the Phanariots. ${ }^{11}$ Later on it received the decisive support of another secular group, the merchants, who challenged the Phanariots for the leadership of Greek society and education and the control of the Church. Because of the close association of the representatives of successive generations of the Enlightenment with these secular groups and the currency of modern ideas in their milieux, another important aspect of the phenomenon of cultural change in the eighteenth century tends to be forgotten: the fact that to a considerable extent the initiatives of educational renewal that opened the way to the introduction of the ideas of the Enlightenment into the thought of Southeastern Europe, came originally from the foremost guardian of the intellectual tradition of the Greek East, the Orthodox Church. The subsequent confrontation between the Church and the Enlightenment in the years of the French Revolution and the hostility evinced by the Patriarchate of Constantinople and its ideological spokesmen to what they saw as the political implications of the ideas of the Enlightenment has obscured the earlier history of educational and cultural initiatives of the Church. The hostility and ideological polemic, however, came after 1793 and more precisely after 1798 . In the 1750 s things were quite different. ${ }^{12}$. This is not to say that the Orthodox Church was prepared to compromise its doctrines and values in favour of modern secular ideas. When issues of doctrine and tradition were felt to be involved, the attitude of the Church was uncompromising. Thus we have cases of persecution of suspect intellectuals such as Methodios Anthrakitis, quite early on in the eighteenth century. Instances of official opposition to modern ideas by the Church, however, are rare before 1789. Cases of individual fanaticism and intolerance, whose recipients were prominent intellectual leaders of the Enlightenment such as Eugenios Voulgaris, Nikiforos Theotokis and Iossipos Moisiodax were more frequent but they did not reflect official church policy or attitudes. On the contrary what is revealed by a careful and non-partisan reading of 
the sources is the ostensibly striking impression that initially the Enlightenment grew from within the Church and it profited to a decisive degree from social practices and institutions established by the Church itself. ${ }^{13}$ In its early phases, before social change and ideological cleavage brought about significant differentiations, the Enlightenment shared the same cultural bases as the Orthodox Church. $\underline{14}$

Practically all intellectuals who were associated with the early phases of the Greek Enlightenment but also with the intellectual revivals of other Balkan nationalities from the 1750 s to the 1790 s were members of the clergy. Concerning the other Balkan nationalities one might mention two monks, Dosithej Obradović and Father Paisi Hilandarski, the spiritual initiators of the Serbian and Bulgarian movements of cultural and eventually national "awakening" respectively. Those Orthodox clergymen who eventually espoused variants of the Enlightenment and secular political values, followed initially the traditional trajectory of social mobility through education in the bosom of the Church. Instead of persisting in the conventional religious framework of thought, however, they reached beyond it to the ideals of science and reason. This of course cost them their careers in terms of further advancement in the ecclesiastical hierarchy. Their original point of departure, nevertheless, was provided by the network of learning sustained by the Church and its monasteries. Furthermore it was the Orthodox Church, at the highest level of its hierarchy, the Holy Synod of the Patriarchate of Constantinople, that placed under its aegis in 1753 the establishment, within the traditional network of Orthodox learning, of a college where secular subjects such as logic, science and Latin were introduced along the traditional religious and grammatical teaching: the story of the Athonite Academy under Eugenios Voulgaris is the most characteristic example of how the pastoral concern of the Church for education opened the way for the introduction of Enlightenment ideas into the very beacon of traditional Orthodoxy. $\frac{15}{}$

Another area in which the movement of the Enlightenment continued practices and built on foundations established by the Church was the recruitment of human resources, through the medium of Greek education and language, from the non-Greek speaking Orthodox ethnic groups and nationalities of the Balkans. This "Balkan dimension" of the Enlightenment and its demographic basis, was equally pronounced in the history and social composition of the Church. The Enlightenment just reproduced a pattern of recruitment practised by the Orthodox Church for centuries throughout the broad area of Eastern Europe - or to paraphrase the late Professor Obolensky, from the domain of the "Orthodox Commonwealth". 16 In this vast territorial domain and more coherently within Ottoman Southeastern Europe, Greek education and the Greek language provided the medium of a cultural unity of Orthodox communities which the Enlightenment inherited from the Church-until this cultural unity was disrupted by nationalism in the nineteenth century. It may appear paradoxical but their ecumenical values, and the social practices these values facilitated, placed the transcendental outlook of Orthodoxy and the secular philosophy 
of the Enlightenment on the same side in the confrontation with the parochial and exclusivist values of nationalism. The irony of the story of course consists in the fact that it was the Enlightenment that paved the way to nationalism, which eventually destroyed the cultural unity on which both the Enlightenment itself and the Orthodox Church had originally thrived.

These inner tensions and contradictions were reflected, occasionally in dramatic ways, in the life stories and intellectual projects of the protagonists of the cultural changes associated with the Enlightenment. By looking at biographical evidence, therefore, we might grasp more immediately the manner in which an earlier intellectual tradition was set on a process of internal transformation. The pre-eminent case of intellectual osmosis and confluence of currents of thought in the eighteenth century was that of Eugenios Voulgaris. His profound sense of the spiritual tradition of the Orthodox East with its hesychastic roots in late Byzantine theology, was combined with a keen awareness of modern science and rationalist philosophy. What sustained both, however, as credible intellectual options in his project of philosophical eclecticism incorporated in his Logic (1766),,$\frac{17}{}$ was their integration into a framework defined primarily by the heritage of classical learning. What is absent from Voulgaris's project is any sense of the historicity of knowledge: ancient Greek mathematics and modern science, Aristotelian metaphysics and Cartesian logic are adduced side by side as equivalent sources of argument and evidence. In the same way the Byzantine ideal of Christian rulership with its ancient Hellenistic origins is treated as a model for reforming enlightened autocracy. A similar syncretism marks Voulgaris's biography: a student of the sciences and a monk, a scholar and a man of the world of power politics, he discovered a common denominator that held all this together in his constant concern for the revival of Hellas, intellectual but also political. $\underline{\underline{18}}$

Voulgaris' student Iossipos Moisiodax is very different and yet complementary to his master, the object of his own admiration and criticism. Although a militant exponent of the secular values of the Enlightenment and an outspoken social critic Moisiodax exemplifies to a striking degree the continuities between the Orthodox tradition of the Greek East and the Enlightenment. His biography is a study in the social meaning of the "Orthodox Commonwealth": a hellenized Balkan clergyman, who studied at the major centres of Orthodox ecclesiastical learning before leaving the Greek world to be immersed in the culture of the Enlightenment in Italy and the Hapsburg lands, Moisiodax harkens back to the heritage of classical learning to an equal degree as he turns to modern science and to the utilitarian philosophy of the Encyclopedists. One aspect of his political thought is most revealing of the way in which the Greek intellectual tradition both provides a basis to and is internally transformed by the Enlightenment: Moisiodax in the 1770s stands at the end of long line of Byzantine and post-Byzantine commentators who employed the parenetic speech of the fourthcentury B.C. Athenian orator Isocrates, In Nicoclem, in order to edify Christian princes. One of the immediate predecessors of Moisiodax in this use of the Isocratic 
text was the Trapezuntine scholar Sevastos Kyminitis who paraphrased the work for the instruction of a pre-Phanariot Wallachian prince. Moisiodax paraphrased In Nicoclem in Modern Greek and in French, the language of cultural change at the time. In doing so he cast his text in such a way as to convey the message that $t^{19}$

"When commands, customs and laws do not conform to the public interest, or when they are of little utility, there should be no hesitation in changing them. It is an act of excessive piety, which indeed is frequently harmful, to preserve old traditions merely because they happen to be old."

Thus staying within a very old and venerable tradition he manages to turn the prescriptions of virtuous rulership into arguments for social and cultural change. The next step in the evolution of his political thought was even more radical: at a moment of intensified conflict with his social environment he discovered in the republican model of civic virtue and free institutions the solution to the problem of corruption in his society. ${ }^{20}$ He thus inaugurated a Balkan tradition of radical republicanism which lingered on for several decades.

A third example from the next generation of scholars will complete our illustrations. In 1815 Neophytos Doukas, another clergyman scholar, an archaist in language and editor of the Attic orators and historians, who was not spared persecution by the opponents of the Enlightenment, urged the Ecumenical Patriarch Cyril VI to mobilize the monks of Athos in an educational crusade in order to spread the Greek language into non-Greek speaking regions of Southeastern Europe and Asia Minor. What Doukas was essentially arguing for was the mobilization of the human resources of the Orthodox Church in a campaign on behalf of the Enlightenment, inspired by a sense of Greek patriotism. ${ }^{21}$ On the threshold of the nineteenth century the obvious inner tensions of this argument announce the dawn of new age. It is the age that witnessed the decisive political turn of earlier general arguments for cultural change and intellectual reconstruction.

Before concluding, by briefly considering in a longer term perspective the significance of the new age ushered in by the Enlightenment, we should make explicit what emerges from the evidence discussed so far. The unifying intellectual element that held together the diverse and often mutually incompatible traditions that make up the cultural personality of the Greek East, was the heritage of classical letters. It was this element that distinguished the Greek East from the vast Slav regions of the Orthodox Commonwealth of Eastern Europe, with which it shared a common tradition of Christian learning and a common culture of sacred letters. Within the Orthodox Commonwealth, however, classical letters appeared as the distinct patrimony of the Greeks. Transmitted by the Byzantine centuries to post-Byzantine culture, preserved although often combatted by the Church, this legacy formed a point of contact and a shared basis upon which much of formal academic culture in the Greek East hinged. 
The relation between the Orthodox spiritual tradition and classical learning is evidently a complex one, marked by inner antinomies and often appearing as a form of combative symbiosis. Basil the Great's solution to the problem of pagan literature in Christian education in the fourth century ${ }^{22}$ and beyond it the literary practice of all the Cappadocian fathers, ${ }^{23}$ nevertheless, provided the ideological basis for the legitimation and ultimate survival of classical letters or at least of the classical language in the form developed during the Second Sophistic, within the Orthodox culture of the Greek East. The survival took the form of the various classical revivals in Byzantine literature. Perhaps more importantly Saint Basil's solution made possible the survival of several Byzantine manuscripts of the Greek classics in the monastic libraries of the East, most notably on Mount Athos. Thus the Orthodox tradition of the Greek East allowed space for the legitimate reception of pagan literature, even though as ancilla fidei.

In the post-Byzantine world the legitimation of classical learning by Orthodox tradition can explain the fact that such a staunch defender of Orthodox doctrine and dogmatic purity, as George Scholarios, who in January 1454 became the first patriarch of Constantinople after the City's fall as Gennadios II, was equally versed in hesychastic theology and in Aristotelian philosophy. It can also explain the phenomenon of Christian humanism in the later sixteenth and especially in the seventeenth century. These phenomena in the Orthodox world had been paralleled by similar earlier currents in the West during the previous two centuries. This configuration represented a survival in Orthodox culture of the earlier Greek humanist movement of the later fourteenth and fifteenth centuries that was absorbed, mostly via Venice but also via Florence, into the mainstream of Renaissance humanism. Scholar prelates such as Meletios Pigas, Maximos Margounios and Gerasimos Vlachos constitute the intellectual successors of Dimitrios Chalcokondyles, Constantine and Janus Lascaris, Manuel Chrysoloras, George of Trebizond and Theodore Gazis. Finally the same intellectual preconditions allowed the appearance of Greek Neoaristotelianism in the seventeenth century: Theophilus Corydaleus, an Athenian who had classicized his name, a student of the Neoaristotelian philosopher Cremonini at Padua, where he was Galileo's contemporary, was installed by the Patriarchate in the 1620s as director of the Patriarchal Academy in Constantinople, with the mandate to upgrade its curriculum and level of instruction. ${ }^{24}$ What made Corydaleus acceptable to the Church and made possible his appointment by the controversial Patriarch Cyril I Loukaris, was not of course his Western education per se, but his accomplished knowledge of Aristotle's philosophy.

The last survivals of the post-Byzantine tradition of Christian humanism lingered on until the opening years of the eighteenth century. They were exemplified for instance in the writings of the famous ecclesiastical orator Elias Miniatis, and found poetic expression in the collection of religious lyricism $A v \theta \eta$ Ev̉ $\lambda \alpha \varepsilon i \alpha \zeta$ [Flowers of Piety], published in Venice in 1708. In the course of the eighteenth century the inheritance of 
Christian humanism became the basis of Greek education. This is indicated by the history of the most successful textbook of the period, the Philological Encyclopedia

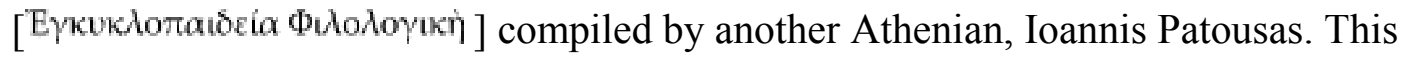
was an anthology of ancient Greek and Christian Patristic literature, used as a manual in the teaching of Greek in advanced, i.e. secondary, schools. Since its first appearance in 1710 from the Greek presses in Venice it went through at least fifteen editions until 1839, including an edition in St. Petersburg in 1811-1814. ${ }^{25}$ This was the immediate substratum, educational and intellectual, of the Enlightenment.

The heritage of classical letters that had been integrated into the intellectual values of Eastern Orthodoxy and lingered on in the diverse forms of Christian humanism we have surveyed, made possible in the first place the reception of the Enlightenment into post-Byzantine culture as a legitimate intellectual pursuit. This in turn can explain a number of seemingly surprising phenomena. The Enlightenment took root and grew in Modern Greek culture mostly in the form of a reorientation toward classical hellenism: from the translation of the fifteen volumes of Charles Rollin's Histoire Ancienne in 1750 to Adamantios Korais's massive editorial project of Greek classics, the Hellenic Library from 1805 onward, $\underline{26}$ Modern Greek society was discovering the moral and political messages of the classical past as a guide to its own future. The earlier selective integration of classical letters into the Orthodox tradition, made it difficult for the Church to resist this reorientation which was secular in content and was to prove profoundly subversive both spiritually and politically. Whereas other integral components of the Enlightenment outlook such as modern science and rationalist philosophy could be openly resisted by representatives of ecclesiastical learning in that they directly contradicted the words of the Scripture, $\frac{27}{}$ the most dangerous part of the project of the Enlightenment, its classicism, could not be so easily denounced, in view of the long history of cultivation or at least toleration of classical letters in the bosom of the Church. How could the Orthodox Church denounce or reject what had been for centuries accepted as an integral component of its educational legacy?

This context of traditions of learning and ideas of cultural legitimacy could also explain one special feature of the Greek Enlightenment, which had to do with its complex attitude toward Byzantium, especially toward the heritage of Byzantine letters as an integral part of the Christian culture of Greek society. The understanding of the place of the Enlightenment in Greek culture has been coloured to a determining degree by the attitudes and views of Adamantios Korais, undoubledly its best known and intellectually its most accomplished exponent. This can explain why the Greek Enlightenment has been understood and interpreted as involving a wholesale rejection and negation of Byzantium. This was certainly Korais's attitude ${ }^{28}$ and it reflected primarily the culture of the French Enlightenment to which he integrally belonged. Others among the leading exponents of Greek Enlightenment culture, however, adopted considerably more nuanced attitudes toward Byzantium. Eugenios Voulgaris 
and Gregorios Constantas produced important editions of Byzantine sources, works by Joseph Bryennios and Synesius of Cyrene respectively in 1768-84 and 1792. This editorial activity, which was motivated by a broad concern for the preservation and propagation of the sources of the Greek intellectual tradition and of Christian knowledge, did not adversely affect the perception of either of them as representatives of the culture of secular "lights" and right reason in the eyes of their contemporaries. It was also in this period, that a six-volume edition of Byzantine chronographical sources paraphrased into Modern Greek under the title Byzantis saw the light as a reflection of the new historical culture associated with the Enlightenment. The logic motivating these editorial projects transpires in a two-volume prosopography of Greek literature published by Anthimos Gazis in 1807. $\frac{29}{}$ This was a chronological listing of major authors who had written in Greek, including the giants of classical literature, followed by authors of the Hellenistic and Roman periods. The representatives of the Roman period of Greek literature included all known authors who had written in Greek down to the fall of Constantinople. The survey was completed by listings of major post-Byzantine Greek writers down to the author's contemporaries. Thus Byzantine literature was incorporated into the overall picture of the Greek intellectual tradition as a bridge between Ancients and Moderns. The special interest of this conception of the unity of the intellectual tradition of Greek literature consists in the fact that it antedates romantic theories of historical continuity, which were to dominate the nineteenth century.

The same view of Greek literature as an all-encompassing tradition is to be found in the writings of the most genuine exponent of philosophic encyclopedism in the Greek Enlightenment, Dimitrios Katartzis. In what is perhaps his most significant work, entitled "An Exhortation to Self-Knowledge", he includes a diagram of knowledge, a cognitive map of human understanding drawing on basic theories of philosophical empiricism from Francis Bacon to D' Alembert. To illustrate his cognitive map Katartzis attempts a listing of Greek books, classified according to a tripartite division of knowledge (Memory-Understanding-Imagination) and its subdivision in particular disciplines. Patristic and Byzantine literature are fully represented on this cognitive map as forms of the creative expression of Greek culture and learning. $\frac{30}{3}$

This kind of evidence, which contextualizes the broader question of the reception of Byzantium by Enlightenment authors may not be without some interest. ${ }^{31}$ It could be read as a pointer to a more historically specific and nuanced understanding of a very broad and many-sided phenomenon, whose complexity is very often obscured by preconceptions and conventional stereotypes.

Let us now draw to a close this far-ranging itinerary during which we have been retracing some of the historical dimensions of Greek culture, by returning to our consideration of the fate of the classical tradition. Reinterpreted by the Enlightenment the heritage of classical learning eventually took up a novel, perhaps even 
revolutionary character. The impact of European political classicism and of the republican models of the French Revolution transformed beyond recognition what the Orthodox East regarded as a part of its heritage. The best known exponents of the later and most mature phase of the Greek Enlightenment, Rhigas Velestinlis and Adamantios Korais, in their very different ways represent this revolutionary classicism in Greek thought. Radical activism on the part of Rhigas ${ }^{32}$ and liberal scholarship in the case of Korais combined in infusing a section of Greek culture with a new identity. It was an identity premised on the espousal of the classical heritage but directed this time against the Orthodox tradition that had nurtured that heritage for so long. In short it was a modern secular identity premised on a reconnection of Modern Greek society with classical republican hellenism. Faced with these unexpected developments the official Church eventually saw what some fundamentalists had been claiming all along: that Orthodoxy could tolerate the classics only at its peril. But when the Patriarchate of Constantinople opened its campaign against classicism during the third patriarchate of Gregory V in 1818-1821, it was too late. The temper of revolution was in the air. The Enlightenment had done its work.

This was the cultural context of the emergence of a new age in Greek history at the beginning of the nineteenth century. From the traditional syncretism of cultural pluralism to the osmosis of a new synthesis the stage had been set for the emergence of a modern literary tradition and the political aspiration of freedom: these were precisely the critical elements that defined the new nation about to appear as an active participant in the drama of European history in 1821.

An earlier version of this paper was presented as the concluding lecture of the conference "The Greek world under Ottoman and Western domination, 15th-19th centuries", held at the Onassis Cultural Centre in New York on 29 April 2006. The original version appeared in the proceedings of the conference, published under the same title in 2008. The version published here has been extensively revised, updated and expanded. In revising the earlier version I had the benefit of the comments and suggestions of Professor Ihor Sevchenko, to whom I am deeply grateful. I am also indebted to Richard Whatmore for his encouragement.

Correspondence address: Institute Neohellenic Research/National Hellenic Research Foundation, Athens, Greece. 
${ }^{1}$ Peter Burke, Varieties of Cultural History (Cambridge, 1997), 189.

${ }^{2}$ For the reader's fuller information it is perhaps relevant to single out here some authoritative sources in English that deal with various aspects of the Greek Enlightenment: Raphael Demos, 'The Neo-Hellenic Enlightenment (1750-1821)', Journal of the History of Ideas, Vol. 19, No. 4 (October 1958), 523-41; Loukis Theocharides, The Greek National Revival and the French Enlightenment, Ph.D. Diss., University of Pittsburg, 1971; G. P. Henderson, The Revival of Greek Thought 1620-1830 (Edinburgh and London, 1971); the collection of representative primary sources ed. by Richard Clogg, The Mouvement for Greek Independence 1770-1821 (London, 1976) and idem, Anatolica: Studies on the Greek East in the 18th and 19th Centuries (Aldershot: Variorum, 1996), Studies VI-VIII, X-XI; P. M. Kitromilides, The Enlightenment as Social Criticism. Iosipos Moisiodax and Greek Culture in the Eighteenth Century (Princeton, 1992). Also Peter Mackridge, 'The Greek Intelligentsia 1780-1830. A Balkan Perspective', Balkan Society in the Age of Greek Independence, ed. by Richard Clogg (London, 1981), 63-84 and Anna Tabaki, 'Greece', Encyclopedia of the Enlightenment, ed. A. Kors (New York, 2003), Vol. 2, 157-60. The classic account is of course C. Th. Dimaras, La Grèce au temps de Lumières (Geneva, 1969).

${ }^{3}$ This and the following paragraphs draw on sections of my article, 'Cultural Change and Social Criticism', History of European Ideas, Vol. 10 (1989), 667-78, esp. 66869.

${ }^{4}$ The process is illustrated by representative texts selected and introduced by N.

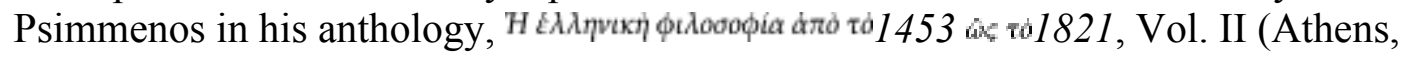
1989).

${ }^{5}$ For a detailed survey see Vasilios Makrides, Die religiöse Kritik am Kopernikanischen Weltbild in Grienchland zwischen 1794 und 1821 (Frankfurt, 1995), 25-74. Note the appraisal by Ihor Sevchenko, 'Copernicus in Orthodox Greece', in Journal of the History of Astronomy 31 (2000), 165-8.

${ }^{6}$ See P. M. Kitromilides,

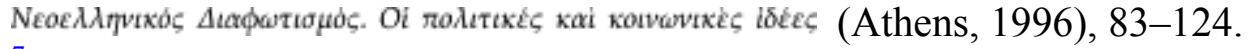

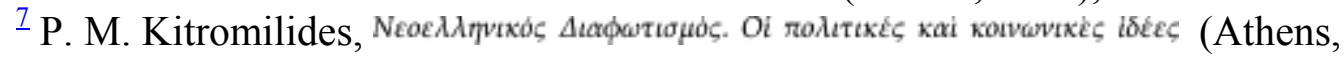
1996), 125-64.

${ }^{8}$ For a discussion of pertinent legislative initiatives, those of Princes Alexander Ypsilanti in 1780 and Ioannis Caragia in 1818 in Wallachia and Ioannis Callimachis in 1817 in Moldavia, and on the juridical environment in the two principalities see Georges Cront, 'Le droit romano-byzantin dans les pays roumains à l'epoque Phanariote', L'époque phanariote (Thessaloniki, 1974), 315-25. The most important such initiative was also the earliest, the abolition of sefdom by Prince Constantine Mavrocordatos in 1741. On this see the contributions by Şerban Papacostea and Florin Constantiniu in L'époque phanariote, 365-76 and 377-84 respectively. Constantine Mavrocordatos' abolition of serfdom was noted in the Mercure de France in 1742.

${ }^{9}$ See P. M. Kitromilides, On the echos of the "debate on the French Revolution" in the Greek context see P. M. Kitromilides "Témoin oculaire de choses terribles': Adamantios Korais, observateur de la Révolution française', Dix-Huitième Siècle, 39 (2007), 269-83.

${ }^{10}$ See Tradition, Enlightenment and Revolution, Ph. D. Diss., Harvard University

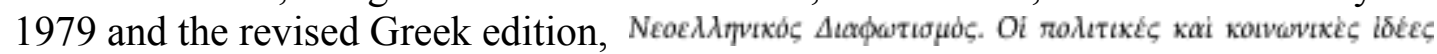
(Athens, 1996). Also the collection Enlightenment, Nationalism, Orthodoxy. Studies 
in the Culture and Political Thought of Southeastern Europe (Aldershot: Variorum, 1994).

11 From a considerable literature see Cyril Mango, 'The Phanariots and the Byzantine tradition' in his collection Byzantium and its Image (London: Variorum, 1984), study no XVIII and for a broader perspective Symposium: L'époque phanariote (Thessaloniki, 1970). For a recent study reappraising the subject see Christine Philliou, 'Communities on the Verge: Unraveling the Phanariot Ascendancy in Ottoman Governance', Comparative Studies in Society and History 51 (2009), 15181.

12 See P. M. Kitromilides 'Initiatives of the Great Church in the mid-eighteenth century', An Orthodox Commonwealth. Symbolic legacies and cultural encounters in Southeastern Europe (Aldershot: Ashgate/Variorum, 2007), Study V.

$\underline{13}$ On the interplay of Orthodoxy and Enlightenment see P. M. Kitromilides, 'Orthodoxy and the West. Reformation to Enlightenment', Cambridge History of Christianity: Vol. V: Eastern Christianity, ed. by Michael Angold (Cambridge, 2006), 187-209, esp. 202-09.

${ }^{14}$ On this shared cultural background in the Balkans cf. P. M. Kitromilides, 'Balkan mentality. History, legend, imagination', Nations and Nationalism, Vol. 2 (1996), 163-91. Reprinted in idem, An Orthodox Commonwealth, Study I.

${ }^{15}$ Cf. P. M. Kitromilides, 'Athos and the Enlightenment', Mt. Athos and Byzantine Monasticism, ed. by A.A.M. Bryer and Mary Cunningham, Aldershot 1996, 257-72 [=An Orthodox Commonwealth, Study VII].

${ }^{16}$ Cf. Dimitri Obolensky, The Byzantine Commonwealth. Eastern Europe, 500-1453 (London, 1971), 202-36, 272-90.

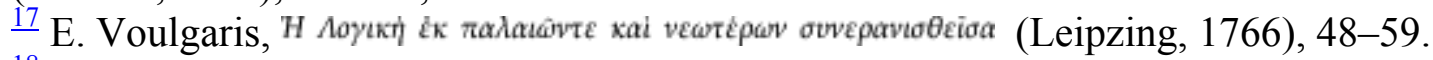

18 See Stephen K. Batalden, Catherine II's Greek Prelate. Eugenios Voulgaris in Russia 1771-1806 (Boulder, 1982) and Martin Knapp, Evjenios Vulgaris in einfluss der Aufklärung (Amsterdam, 1984). The latter work is a study of Voulgaris' treatise on religious toleration, pointing to the limits of Voltaire's influence upon his thought. $\underline{19}$ See Iosipos Moisiodax,

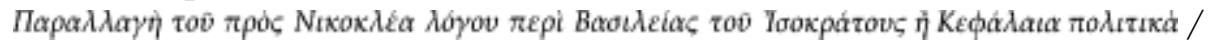

Transformation de l'Oraison d'Isocrate sûr l'art de régner pour Nicoclés ou Chapitres politiques (Venice, 1779), 13. Cf. Kitromilides, The Enlightenment as Social Criticism, 170-71. On earlier expressions of the tradition of reflection on virtuous ruleship in the principalities see Andrei Pippidi, Byzantins, Ottomans, Roumains (Paris, 2006), 95-120, 255-66.

${ }^{20}$ Iosipos Moisiodax, Arodoria(Vienna, 1780), 181-82 and on the significance of his republican vision, Kitromilides, op. cit., 167-82.

${ }^{21}$ On Doukas's views and their significance cf. P. M. Kitromilides, 'Imagined communities and the origins of the national question in the Balkans', European History Quarterly, 19 (1989), 156-59. For a detailed and comprehensive study of the

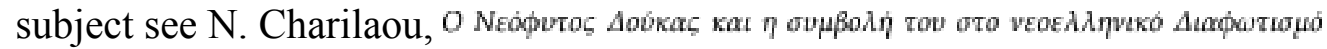
(Athens, 2002).

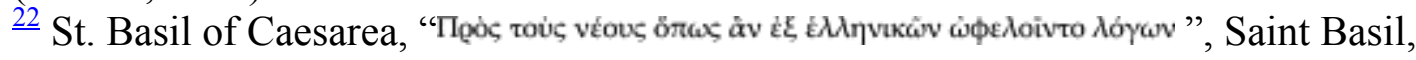
The Letters, Loeb Classical Library (Cambridge, Mass. 1970), Vol. IV, 363-434. This text, of course, was much more popular in the Renaissance than it had ever been in Byzantium, where it lingered hidden as Homily 50 in manuscripts of Basil's works. ${ }^{23}$ See Ihor Sevchenko, 'A Shadow Outline of Virtue: The Classical Heritage of Greek Christian Literature', The Age of Spirituality, ed. by Kurt Weitzmann (New York, 1980), 53-73 [=idem, Ideology, Letters and Culture in the Byzantine World, 
Variorum 1982, Study II].

${ }^{24}$ The standard source is $\mathrm{Cl}$. Tsourkas, Les débuts de l'enseignement philosophique et de la libre pensée dans les Balkans. La vie et l'oeuvre de Théophile Corydalée

(Thessaloniki, 1967). See also Henderson, The Revival, 12-9.

$\underline{25}$ On this work and its content see Athanasia Avdali,

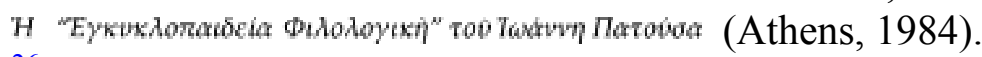

${ }^{26}$ On Korais and his projects in the classics see most recently the meticulous work by

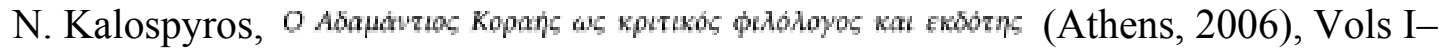
II.

27 See V. Makrides, Die religiöse Kritik, 81-211.

$\underline{28}$ Note characteristically his critical exposition of Byzantine history, drawing extensively on the French translation of Edward Gibbon's Decline and Fall of the

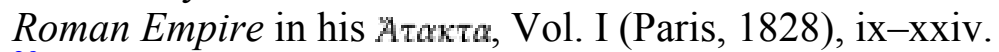

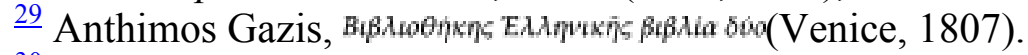

${ }^{30}$ D. Katartzis' relevant texts are assembled in his Tó $\varepsilon \dot{\rho} \rho \iota \sigma \kappa \delta \mu \varepsilon v a$, ed. by C. Th. Dimaras (Athens, 1960), 94-203.

${ }^{31}$ For an evocative survey see Anna Tabaki, 'Byzance à trevers les Lumières néohelléniques', Europe. Revue littéraire mensuelle, no. 822 (October 1997), 147-61.

$\underline{32}$ See P. M. Kitromilides, 'An Enlightenment perspective on Balkan cultural pluralism. The republican vision of Rhigas Velestinlis', History of Political Thought 24 (2003), 465-79. 